\title{
STORYTELLING AS A FORM OF POLITICAL PROPAGANDA. POLITICAL PROTESTS IN HONG KONG IN THE NARRATIVE OF RT AND CCTV NETWORKS
}

\begin{abstract}
The article contains an analysis of contextual models used for propaganda activities carried out in two state television stations - RT and CCTV, in connection with the protests in Hong Kong that have been ongoing since June 2019. The research, referred to in the text, is an analysis of the narrative created in connection with the protests on both televisions in the context relevant to the achievement of propaganda goals by broadcasters. Storytelling built a one-sided picture of events as a tool for persuasion and influence on public opinion using the existing social and political polarization. The research was carried out using the quantitative and qualitative method. The obtained conclusions are part of the research on propaganda and contemporary distribution channels to create alternative images of reality using contextual models by mass media positioning themselves as state broadcasters.
\end{abstract}

Keywords: RT, CCTV, propaganda, storytelling, extradition Bill, Hong Kong

\section{Introduction}

The protests that began in Hong Kong in June 2019 were the response of the local community to subsequent attempts to limit the autonomy of the region undertaken by the People's Republic of China (hereinafter called the PRC) since 2010. Hong Kong's society is strongly polarized, which results from the fact that the region is inhabited by residents showing a strong local identity and newly arrived Chinese citizens settling in the region after 1997 (Lui, 2015; Ma, 2015; Lo et al., 2019). The intention to introduce legal regulations that would allow the extradition of people suspected of committing crimes to be tried in Mainland China were met with 
sharp and decisive opposition by some Hong Kong residents, perceiving the region as a haven of freedom for political dissidents and oppositionists of the communist party. Protests, which grew in force over time and caused objective obstacles not only for Hong Kong's residents (seizing the international airport for several days), generated more and more media interest in the world, causing also the propaganda media to take a stand on events in the autonomous region of China. The article presents stories related to protests in Hong Kong treated as propaganda, built by two TV channels - the RT and CCTV, using contextual models inscribed in ideologies that are sources of propaganda messages. The theoretical context of the research was determined by the theories of propaganda and narrative storytelling by journalists, taking into account contextual models that were used in the creation of storytelling.

The research objective was to determine the contextual models adopted by television stations which remain at the disposal of the authorities using propaganda to persuasively influence public opinion when reporting on the events in Hong Kong, adopting a specific narrative and using terms describing the participants of protests. The choice of two TV stations that use different sources of message creation in the propaganda narrative and building the story concerning the protests was made taking into account the variable of the relative location of the protest towards the administrator of the propaganda media. For the PRC, the protests in Hong Kong were acts of internal resistance directly affecting the image of the state, while for Russia these were external events not directly related to the implemented policy.

\section{Theoretical frames}

Propaganda is a form of communication which is attributed the nature of persuasive influence on the recipient and modification of his or her attitudes. The multitude of definitions indicates different perspectives for analyzing propaganda activities, which, in conjunction with communication acts and broadcasters, are significantly correlated with media development (Herman and Chomsky, 1988; Taylor, 2003; McQuail, 2010; O’Shaughnessy, 2012; Lasswell, 2013; Rieger et al., 2013). According to the definition of propaganda by Garth S. Jowett and Victoria O'Donnell (1999, p. 6), indicating that propaganda is purposeful and systematic actions that aim to shape beliefs, manipulate knowledge, attitudes and behaviors in a manner consistent with the propagandist's expectations. By introducing a distinction between two concepts: "informational communication", i.e. a selected set of informational messages or instructing recipients, and "persuasive communication", leading to a change in behavior or reaction, or to strengthening attitudes as a result of acceptance and adaptation of the content of the message, the authors refer to psychological actions, leading to shaping perception, manipulating thoughts, and direct behavior in order to achieve responses in line with the propagandist's 
intentions. In political propaganda, attention is paid to the relations of propaganda content to current problems that are associated with ideas and values, which leads to a situation where statements classified as propaganda are not so much based on facts but they only relate to them. Considering that in the article the area of research was located in televisions whose broadcasters are entities that do not hide the ideology and intentions of the propaganda messages formulated, propaganda activities should be classified as white propaganda. It serves the purpose of building the credibility of the sender who wants to openly convince recipients of their ideological beliefs (even if they do not define them in such a way directly). Kingsley Edney indicates cultural connotations of propaganda definition in the context of Chinese activity interpretation. Edney writes: "Original meaning of the term in the West refers to the spreading of a philosophical argument or opinion, before mentioning that in the West the term is now commonly used in the context of supporting a particular government or political group. It then offers the following three definitions of xuanchuan in the Chinese context: to announce or convey information (xuanbu chuanda); to explain something to someone, or to conduct education (xiang ren shuoming jinxing jiaoyu); or to disseminate or publicize (chuanbo, xuanyang)." (Edney, 2014, p. 92) The story created by propaganda narrative, reference was also made to the definition of Ian Kershaw (1983, pp. 180-205) emphasizing the importance of the social environment for the effectiveness of propaganda. The effectiveness of propaganda results from its relationship with the existing consensus, values and prejudices that can be used to strengthen the message: where there is a conflict of values and a deficit of two elements: clearly defined divisions and clear stereotypes, the effectiveness of propaganda is weakened. Similarly Philip Taylor (2003, pp. 5-12) defined propaganda as a process designed to seduce people into believing something that they would not otherwise have believed as well as the intent is to persuade people to think and behave in a way desired by the source. He claims propaganda use emotions and in post-industrial society people become consumers so the propaganda is paid by others like states. Two propaganda functions are particularly important for these considerations. The integrating function that stabilizes and strengthens the political and social system, its foundation is the culture of the nation or group you want to influence. The second is the informative and interpretative function, combining elements of information and interpretation, creating a persuasive message. The implementation of the informative and interpretative function creating a persuasive message is achieved through an appropriate narrative that builds storytelling using specific myths and values, relevant to the content sender. The creation of persuasive messages is carried out as a result of ideological discourse, in which ideology is treated as a way of presenting the world. In the opinion of Teun A. van Dijk (2009, pp. 193-194) in this way contextual models are created that serve to control information activities carried out by editorial offices. Contextual models of creating information include the course of events and their participants and they also take into account current goals, knowledge and 
fit into the social ideologies of the participants. This means that defining a context constraint is a key message creation filter. Contextual models can therefore either block or modify (soften or strengthen) ideological beliefs, which are generally polarized, based on the positive determination of one's own group at the expense of another. One of the basic mechanisms of using the contextual model in the semantic aspect are the terms describing supporters or opponents of implementing a particular policy. The example given by van Dijk comes from his research on the discourse conducted in the New York Times and The Washington Post, which revealed the ideology existing in the United States towards Arabs (in the face of the crisis in the Middle East), who were described as "terrorists" in some texts. At the same time, such a concept was never used to describe the Israeli attacks on Palestinians. The clear polarization of the concepts resulted from leanings and existing alliances with one of the parties to the conflict, towards which the concepts were mitigated (Van Dijk, 2009, pp. 198-199).

Analyzing storytelling using a narrative creating a specific persuasive message, Elizabeth Bird and Robert W. Dardenne (1988) noted that the information presented by journalists is not merely limited to reporting facts, but is a form of a story. According to researchers, journalists use conventional stories to define the world in a way that reflects and strengthens the viewers' ideas, referring to existing ideologies, mainly cultural and social, and constructing specific narratives. In subsequent research findings, Bird and Dardenne (2009, p. 211) emphasize that narratives appearing in journalistic materials perform the role of narrative impulses, which, thanks to new technologies, deepen history through public negotiation of meanings. Technologies cause changes in the position of information recipients, who take over an active role, thereby developing and transforming information, not just consuming it. Another change takes place in the consequences of network information, modified by their virtual recipients, who should be treated as co-authors of the narrative. According to Andrew Keen (2007, p. 80), the result of such participation in the creation of a narrative is the emergence of a relativistic world in which a common narrative is not told, and consequently, no common myths are created that would bond the community. Analyzing the theory of storytelling in the context of the network phenomenon of tribalism, it should be noted that network tribes, by creating their shared narratives, at the same time create myths that are bond-forming, identifying the identity resulting from belonging to a specific community. Therefore, many worlds are created, which function side by side, building alternative realities based on certain narratives told, with an explicitly directed message characterized by emotion. 


\section{Techniques and sources of Chinese and Russian propaganda}

Gary Rawnsley $(2015$, p. 2) considers both televisions, which were adopted in the article as the space for research in the area of communication about acts of civil disobedience in Hong Kong, as tools of both propaganda and conducting public diplomacy by the PRC and Russia. The goal of each television is to communicate with an international audience and to support the ambitions of politicians in Beijing and Moscow in the field of foreign policy implementation. Rawnsley emphasizes that CCTV is to correct interference in the global flow of news about China, and RT to conduct a kind of a pro-Russian campaign. Communication activities in both cases consist in practicing professional and nearly objective journalism while serving the interests of the state, which each station represents. As Rawnsley points out, this is particularly difficult for both China and Russia. In PRC, television is embedded in the state system, while in Russia it is involved in international and diplomatic crises. Hence, it seems particularly difficult for each television while creating information activities to avoid a simple accusation of propaganda activities in its negative sense. One of the important activities undertaken by both TV stations to avoid associations with propaganda activities is to conduct communication using social networks, allowing them to study the reception of content shared there, to analyze the comments of network users and to respond to formulated allegations, which apparently increases the credibility of messages. Both televisions use and are active in all important global communication channels - YouTube, Facebook, Twitter, although their use in Mainland China is blocked. ${ }^{1}$ Activities with the use of information and communication technologies are an important element connecting efficient propaganda with modern public diplomacy. As James Pamment (2013, p. 3) indicates, activities carried out in the field of public diplomacy may have the character of a "one-way flow of information", which indicates that it is important for the sender to provide information to the recipient, which clearly identifies communication activities with propaganda, while modern public diplomacy is based on a dialogue activity that allows the recipient to know the opinion and situation assessment by expressing their opinion using social media. The mechanisms of functioning of network communities emerging around entities create specific enclaves of deliberation, in which the discourse around the analysis of the transmitted content usually takes place in groups of people with similar views, which give meaning to the discussed content and increase their network coverage (Maffesoli, 1996; Mihailidis and Viotty, 2017; Bossio, 2017, p. 246; Sunstein, 2018, p. 75; Watts, 2018, p. 217). Thus, despite conducting activities of the nature of modern public diplomacy (dialogue form and cooperation with the public), both communication acts

1 YouTube subscriptions (CCTV - 216 thousand, RT - 3.69 million), Facebook fans (CCTV - 50 million, RT - 5.6 million), followers on Twitter (CCTV - 800 thousand, RT - 3 million) - data on 27.09.2019. 
and network discourse around them are burdened with a credibility deficit, focusing de facto on spreading a unilateral picture of the situation in the network, which may possibly be confronted with other images created by the alternative community. As Denis McQuail (2000, p. 134) writes, social media facilitates propaganda bias (in connection with tribal attitudes and network behavior). This occurs through the selection of emotionally-marked vocabulary and as a result of the creation of messages containing implicit comments. The seemingly objective presentation of the case evokes a certain emotional character due to the words used in the context of interpreting the message; using value-laden words that evoke prejudices and stereotypes; selecting posted content, and at the same time deliberately omitting some. But Nicholas Cull treats social media only as a useful tool to spread information. He writes: "The era of social media has opened up fresh possibilities, but it has not erased the relevance of the history of public diplomacy. (...) Whether the communication travel electronically at the speed of light or in hand delivered notes written with quills, the underlying foundations remain as valid today as they were when the term 'public diplomacy' was coined in the 1960th, or when in previous centuries, generations practiced the art oblivious to its name" (Cull, 2019, p. 170).

The sources of Chinese propaganda should be sought in Confucius' theory, which the communist party used in the PRC after releasing the mechanisms of the local economy and for fear of social unrest resulting from social inequalities that could threaten the status of the ruling party. The Communist Party of China reached for Confucian cultural heritage because of the values of social stability, hierarchy, and respect for power (Edney, 2014, pp. 29-33). In the spirit of Confucius' philosophy, messages are created about the party's activities for society, the respect it expects, and maintaining social order. According to John Dotson (2011, p. 3), the communist party cited the need for "social stability" in propaganda campaigns both at home and abroad, confirming China's desire to create a "harmonious society" and "peaceful development". Hong Zhang (2011, p. 576) points out, that China's television policy is treated as a means of strengthening the ideological dominance of the party-state, while the messages are addressed to both the Chinese society and the international community.

Russian propaganda uses conspiracy theories as a populist theory of power, which legitimizes Russia's internal and external policies while simultaneously delegitimizing the policy of primarily the American government. Using the context of the post-Cold War world, according to Ilya Yablokov (2015, p. 301), RT is building a conspiracy message, using it as a political instrument to attract global audiences from different political views. Thus, the purpose of messages broadcast in RT is to undermine the policy pursued primarily by the US government, while at the same time strengthening and lending credence to the policy pursued by Russia. Mark Fenster $(1999 ; 2008$, pp. 84-91) pointed to conspiracy theories as an important tool in building political strategies to exploit political, economic or social inequalities in political rhetoric. Conspiracy theories formulated in communication acts allow to 
integrate people into a group against the identified and named "the other". Fenster's theories were developed by Ernesto Laclau (2005, pp. 37-38), arguing that the antagonistic division of the community into two camps: "us" and "them" is aimed at undermining social order and gaining power. The conspiracy narrative that binds the "people" against the "other" aims to create anxiety that is based on concerns about inequality but also undermines the position and reputation of the "other" who, according to the sender, benefits from plotting against the "people" (Fenster, 2008, pp. 89-90). Yablokov (2015, p. 302) proves that for Russia the "other" is the West, imagined as "one undifferentiated being". Fears arise from resentments (divergences between Russia and its ideal - the West) or anti-Western views, according to which the West appears to be the "other" undermining the progress of the Russian people. As indicated by a Polish researcher of Russian propaganda, Joanna Darczewska (2014, pp. 18-19), the anti-Western rhetoric is used as a means in domestic politics: before, it built the demand of citizens for a strong state with international authority; today it is building the mobilization readiness of society, strengthening the sense of danger from the West. The other recipient is the public opinion in the countries of the CIS. Its acquisition is to facilitate the implementation of the Kremlin's geopolitical goals, such as: maintaining influence in the former USSR or preventing integration of post-Soviet states with the West. Both these dimensions - internal and regional, are closely intertwined, which makes the concept of the Eurasian world possible. The struggle for obtaining information advantage is played by the Russian Federation opposing ideologically traditional and conservative values, the ideology of liberalism, which is accompanied by individualism, technocracy, and globalism. The creation of a conspiratorial narrative by RT is falling on fertile ground, generating an anti-elitist message in which RT becomes a "spokesperson" for the global community and uses the idea of a conspiracy to destroy the reputation of the West, especially the US. These activities create the image of Russia as a leader of global resistance to Western policy. As Sinikukka Saari (2014, pp. 311312) emphasizes, there is currently no ideological component in RT's messages, and it has been replaced by anti-Western and anti-American rhetoric and conspiratorial discourse that allow benefiting from crises in relations between third countries and supporting critical opinions on the policy pursued by Western countries and their leaders.

To sum up the considerations, Russian and Chinese propaganda activities are based on the creation of an ideologically based context model (the PRC) or using conspiracy theories (Russia). Both TV channels are tools for implementing propaganda, they provide information of limited credibility, subordinated to the narrative of their holder also via Internet. By using content building a specific image of the world created through the selection of information, they trigger social integration and create network enclaves of deliberation, causing that the story told as a result of a specific narrative becomes a source of transmedia storytelling in new media, particularly social media (Jenkins, 2008). Transmedia storytelling according 
to Jenkins is a multi-threaded and diverse story that is revealed on various media platforms, with each medium having its own separate contribution to the creation and development of a fictional world. The result is a continuous circulation of content, causing one story to be told many times, using various media. By processing the authentic and original content of message comments, the discourse is enriched with new perspectives, creating in the narrative a wider picture of reality that can be relevant for online and offline participation in civic and political activities. The culture of convergence, which is important not only for the interpenetration of the impact of various media but also for deepening cooperation, causes the same story to be told by different media many times. The choice given to the content consumer mobilizes them to actively seek and participate in learning about the reality that intrigued them. Thus, creating stories by constructing a specific narrative in propaganda television means giving them an independent existence, which as a result of users' network activity can be changed, developed and whose coverage is increased.

\section{Research methodology}

The research was carried out using the quantitative and qualitative method. In the course of the research, the total number of published information was measured and the content of the RT and CCTV websites was analyzed to categorize information illustrating the story presented on both televisions. The content was categorized according to the classification key developed after analyzing the examined texts (leading topics tackled in each published text), but before assigning individual materials to a specific topic. The measurement units were therefore of a content nature, resulting from the topics of publication and terms used to describe demonstrators. In each measurement unit the leading themes and overtones of the content were identified, assigning them to only one thematic category. As a result of categorization, content groups were created that corresponded to specific topics defining the framework for storytelling in the studied televisions. Information that does not correspond to the topics listed is assigned to the "other" category. A comparison was also made (the results are presented in Table 3 ) of the terms used to describe the protesters. The analysis comprised materials published in the period 1-30 August 2019 on the websites of both TV stations in the English language version, because both TV channels run their social media websites, where the content is made available, in this language. The choice of the research period was justified by the fact that the protests were most violent in the examined period, thus causing public interest and activating broadcasters to increase interest in the events in Hong Kong. In the course of research the hypothesis was adopted that propaganda activities are implemented as a result of selection of information that determines the context model on the basis of which storytelling is created. The context model is framed by 
propaganda ideology adopted by each of the broadcasters. Ideology in the adopted hypothesis is defined after Teun van Dijk as a way of seeing and creating the world.

Research questions adopted to confirm or refute research hypothesis were:

1. Was the context model according to which the protest was reported framed by propaganda ideology adopted by each of the broadcasters?

2. How did broadcasters' localization towards the protest influence the creation of storytelling about the protest in Hong Kong?

\section{Findings and discussion}

\section{Chart 1. Topics of articles published in RT}

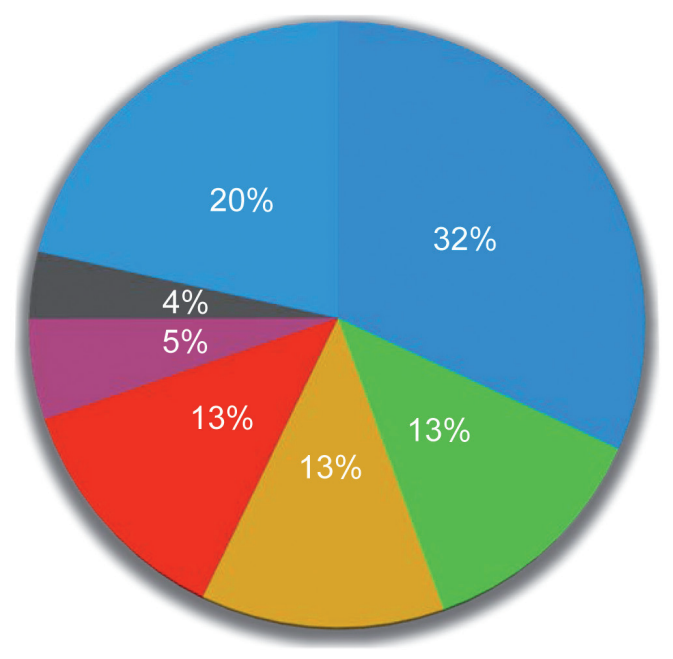

USA's interference in China's internal affairs - 32\%

Aggression of protesters (presented as entities initiating actions) - 13\%

Controlling protests by external entities $-13 \%$

Censorship of social and content media - 13\%

Alleged hypocrisy of Western media in presenting selected protests - 5\%

Protests as a result of British colonialism (a combination of events in Hong Kong and Kashmir) - 4\%

Other $-20 \%$

A total number of 56 articles were published on the RT television's website. During the period under review, no information appeared that would relate events only in the context of the transmission of facts. Each of the pieces of information was analyzed and interpreted in accordance with the intentions of the sender (in addition, the materials were enriched with short film reports, photos or tweets of 
third parties, which reinforced the version of events presented in the article). The contextual model of the Hong Kong protests shows that the events are controlled externally (here a direct reference was made to similar events in Ukraine, Venezuela, Syria or Iran), mainly with the engagement of the United States (although the United Kingdom and EU were also indicated - not specifying countries, but treating the organization as one entity), in which aggressive and frustrated young people participate, used in the political game which is part of the trade war between the US and China. The evidence to support these theses was, among other things, information cited in the articles that demonstrators use American and British flags during marches, and that one of the pro-democratic opposition leaders, Joshua Wong, met with the American diplomacy representative in Hong Kong Julie Eadeh. Police in Hong Kong remain reactive in their actions, taking them only in the face of public order disturbances and protesters' aggression. Western mainstream media (the texts include, among others: CNN, BBC, NBC, Reuters Agency) conduct a non-transparent information policy, ignoring information about some events while simultaneously publicizing other (in several materials the mainstream media's attitude to Yellow Vest protests in France was compared, which are ignored.) According to RT, similar practices took place in the case of EuroMaidan - events in Ukraine at the turn of 2013/2014, where protests were promoted as pro-democratic and libertarian. In its August 27 article, RT reminds that as French protests continued, many Western news sites began calling Yellow Vest demonstrators "rebels" instead of "protesters". At the same time, global social networking sites (YouTube, Facebook and Twitter) used during Hong Kong protests are conducting non-transparent activities, removing accounts belonging to Chinese users and accusing them of propaganda activities and using bots for disinformation purposes. It should be noted that Twitter in particular began deleting accounts following allegations of accepting advertising purchases from the Chinese news agency Xinhua, which criticized Hong Kong protesters. However, as RT argued in several texts, the rules for the selection of accounts that are subject to deletion are unclear and non-transparent, which in itself is an undemocratic and ideologically marked activity because PRC residents have the right to express their views. The image of events shaped by texts published in RT further strengthened the information in which the US was ironically treated, titling the articles: "Beijing to US: Don't 'stick your nose' in China's Hong Kong affairs"; "Twitter diplomat? Trump wants to arrange meeting between China's Xi and Hong Kong protesters"; "What happened when she 'supported' Libya? Chinese media roasts Hillary Clinton over Hong Kong". The persuasive-ironic character of the message was to affect primarily those recipients in Western Europe and North America who contest the policy of their own countries and also see the ambiguity of actions taken in contemporary Western democracies. The narrative context outlined in this way at the same time includes articles in which global luxury brands such as Versace, Coach and Givenchy apologize to China for recognizing Hong Kong, Macao and 
Taiwan as independent state entities. It was described how quickly brands reacted in network communication channels (Donatella Versace personally apologized in social media, in addition, her apologies were shared on the Weibo channel, which is widely used by the Chinese), which proved how strong and important player in the international arena China remains, regardless of its trade war with the US.

Several pieces of information published by RT referred to statements or positions regarding protests published by Chinese media.

Table 1. Examples of published content on

\begin{tabular}{|l|l|}
\hline Categorization key & $\begin{array}{l}\text { Excerpts from articles published on the subject } \\
\text { indicated along with the date of publication }\end{array}$ \\
\hline Interference in China's internal affairs & $\begin{array}{l}\text { "China has denounced US lawmakers and officials } \\
\text { for openly supporting the ongoing demonstrations } \\
\text { in Hong Kong, describing their comments as hy- } \\
\text { pocritical and motivated by Washington's desire } \\
\text { for global dominance." (31.08.2019) } \\
\text { "Trump has recently linked the success of a trade } \\
\text { agreement with China to Beijing's policies towards } \\
\text { the Hong Kong protests, which have been ongoing } \\
\text { for weeks. The president said that a violent crack- } \\
\text { down on the protesters would make the deal much } \\
\text { harder to sign. Beijing urged Washington to stay } \\
\text { out of its domestic affairs." (22.08.2019) } \\
\text { "A newspaper operated by China's Communist } \\
\text { Party pulled no punches on Hillary Clinton's } \\
\text { support for Hong Kong protesters, noting her } \\
\text { role in past foreign policy debacles ranging from } \\
\text { the Iraq War to US intervention in Libya. (...) The } \\
\text { accompanying video shows clips of Hillary } \\
\text { Clinton throughout her tumultuous political } \\
\text { career, advocating for wars and foreign policy } \\
\text { positions that have led to the deaths of hundreds } \\
\text { of thousands of people across the Middle East and } \\
\text { North Africa." (16.08.2019) } \\
\text { "China rebuked Donald Trump for his Twitter- } \\
\text {-conveyed alarm over the amassment of troops } \\
\text { near Hong Kong. The US should mind its own } \\
\text { business and let China's domestic affairs be, it } \\
\text { said." (14.08.2019) }\end{array}$ \\
\hline
\end{tabular}


Controlling protests by external entities

"Beijing has repeatedly accused Washington of providing direct and indirect support to protesters in the semi-autonomous territory, and has even alleged that the US is 'insanely involved' in anti-Chinese extremism in Hong Kong." (31.08.2019) "The ongoing protests in Hong Kong, arguing that 'the gravy train is over' and that the youth, angry over the island's economic stagnation, were manipulated by anti-Beijing media tycoon Jimmy Lai." (29.08.2019)

"There does come a point, however, when the question of 'what' is behind the protests must give way to the question of 'who' is behind them?

Far be it from me to allege or claim the active involvement of external forces. But equally it would be utterly naïve, given the malign legacy of the series of so-called 'color revolutions' in Eastern Europe in the 1990s, Maidan, Kiev in 2014, and other places too numerous to mention, to completely rule out the possibility." (09.08.2019)

Censorship of social and content media

"'borderline content' - like 'sowing discord', the excuse used to deplatform hundreds of channels earlier this month for their opposition to the Hong Kong protests - has no official definition, allowing moderators to delete any channel they want without having to produce proof any rule has been violated." (28.08.2019)

"YouTube has disabled 210 channels for posting content related to the Hong Kong protests 'in a coordinated manner, following in the footsteps of Facebook and Twitter in restricting its arbitrary censorship to pro-China accounts." (23.08.2019)

"We hear so much about the state-controlled media' of Russia, China or any other 'official enemy' pumping out 'propaganda', but if we look at this with total objectivity we will see that the most deadly propaganda - misinformation which has led to the deaths of hundreds of thousands, if not millions of people - has come from elsewhere. It's come, ironically enough, from those outlets which spend so much time accusing others of being propagandists." (20.08.2019)

"Twitter claims to have suspended 936 accounts, reportedly originating from mainland China, which they said appeared to be part of a coordinated state-backed campaign to criticize the protests in Hong Kong. Facebook said it also removed a number of 'fake' accounts and pages linked to people associated with the Chinese government after a tip-off from Twitter. On Tuesday, Chinese Foreign Ministry spokesman Geng Shuang refused to comment on the claims made by the social media giants, but said Chinese people 'have the right to express their point of view' on the protests." (20.08.2019) 


\begin{tabular}{|c|c|}
\hline $\begin{array}{l}\text { Alleged hypocrisy of Western media in present- } \\
\text { ing selected protests }\end{array}$ & $\begin{array}{l}\text { "The CNN guide instructs budding protesters on } \\
\text { exactly 'what to wear' if they want to stay safe, just } \\
\text { like the 'seasoned pros' who have been pounding } \\
\text { the pavements for weeks already (...). The } \\
\text { provocative protesters' manual is a clear indication } \\
\text { that Western media is not merely providing } \\
\text { informative news coverage of the anti-China } \\
\text { protests, but actively backing and supporting } \\
\text { a violent uprising abroad." ( } 27.08 .2019 \text { ) } \\
\text { "The raging protests have been blamed for } \\
\text { downturns in the city's tourism and hotel sectors, } \\
\text { while clashes at Hong Kong International Airport } \\
\text { were immediately presented by the New York } \\
\text { Times as cause for waning confidence in the } \\
\text { city's status as an international financial hub." } \\
\text { (22.08.2019) } \\
\text { "The news is dominated by Hong Kong, and } \\
\text { yet } 29 \text { miles from England is France and this } \\
\text { extraordinary rebellion of the "yellow jackets" that } \\
\text { has produced an equally extraordinary violence } \\
\text { from the state and has been virtually ignored' John } \\
\text { Pilger told RT's Going Underground program. } \\
\text { The explanation of course is that the US and its } \\
\text { allies are in a state of virtual war against China, } \\
\text { the goal of which is to 'maintain supremacy in all } \\
\text { areas of human affairs', he said." ( } 21.08 .2019 \text { ) }\end{array}$ \\
\hline $\begin{array}{l}\text { Violence and aggression of protesters (presented } \\
\text { as entities initiating actions) }\end{array}$ & $\begin{array}{l}\text { "Protesters in the autonomous area of } 7.4 \text { million } \\
\text { people threw Molotov cocktails and bricks at } \\
\text { police, with law enforcement resorting to gas } \\
\text { grenades and water cannon." ( } 31.08 .2019) \\
\text { "Protesters used clubs and projectiles to attack } \\
\text { police on the streets of Hong Kong, a newly posted } \\
\text { video shows, contradicting the western narrative } \\
\text { which had painted the anti-China demonstrators } \\
\text { as noble victims." (26.08.2019) } \\
\text { "Demonstrators were seen digging up bricks from } \\
\text { the street to use as projectiles, as police deployed } \\
\text { tear gas to restore public order. Police had earlier } \\
\text { warned that they would conduct a 'dispersal } \\
\text { operation' and urged demonstrators to leave." } \\
\text { ( } 25.08 .2019) \\
\text { "The protesters erected barricades, marched } \\
\text { to police stations, and hurled bricks and petrol } \\
\text { bombs at officers. Riot police used tear gas to } \\
\text { disperse the unruly crowds." (12.08.2019) }\end{array}$ \\
\hline
\end{tabular}




\begin{tabular}{|c|c|}
\hline $\begin{array}{l}\text { Protests as a result of British colonialism (a com- } \\
\text { bination of events in Hong Kong and Kashmir) }\end{array}$ & $\begin{array}{l}\text { "Though distance-wise Hong Kong and Kashmir } \\
\text { may be about } 4,000 \mathrm{~km}(2,485 \text { miles }) \text { apart, } \\
\text { they have in common a history of being scarred } \\
\text { by the crimes of British colonialism. (...) The crises } \\
\text { which have engulfed Hong Kong and Kashmir } \\
\text { make a strong case not for British interference } \\
\text { but for British reparations. This in compen- } \\
\text { sation for London's role in laying the historical } \\
\text { ground for the strife and unrest now taking place." } \\
(16.08 .2019)\end{array}$ \\
\hline $\begin{array}{l}\text { Other (protest materials that do not fall under } \\
\text { any of the above categories) }\end{array}$ & $\begin{array}{l}\text { "RT America's Sara Montes de Oca asked the pro- } \\
\text { testers why they are not satisfied with the } \\
\text { government's response to their demands, which } \\
\text { appear vague at best. 'The bill was not withdrawn, } \\
\text { there was no independent investigation, I don't } \\
\text { recall the rest of the three like precisely, but I am } \\
\text { sure none of them were answered in a constructive } \\
\text { way', one protester said." (23.08.2019) } \\
\text { "After a video appeared online earlier this month } \\
\text { showing protesters defacing the Chinese flag, } \\
\text { a number of Chinese and Hong Kong celebrities } \\
\text { took to social media to voice their patriotism, } \\
\text { including Chan, who exclaimed 'I am the flag } \\
\text { bearer!' in a recent post on the Chinese blogging } \\
\text { platform Weibo. (...) Chan is not the first Chi- } \\
\text { nese celebrity to find himself in the crosshairs of } \\
\text { internet outrage this week. Liu Yifei, the star in } \\
\text { Disney's upcoming live-action remake of Mulan, } \\
\text { an animated } 1998 \text { film, faced down angry tweeters } \\
\text { on Thursday after writing a post in support of the } \\
\text { Hong Kong police force." (16.08.2019) } \\
\text { "Luxury brands Coach and Givenchy have rushed } \\
\text { to reassure Chinese customers that they respect } \\
\text { Chinas territorial integrity after they found them- } \\
\text { selves in hot water over products listing Hong } \\
\text { Kong and Taiwan as separate countries. (...) In } \\
\text { addition to gaffes by European brands, watchful } \\
\text { Chinese social media users noted that Japanese } \\
\text { sports brand Asics had made similar mistakes on } \\
\text { its website, listing Chinese regions as independent } \\
\text { countries. Asics China was quick to issue an apo- } \\
\text { logy, stressing that it respects the country's territo- } \\
\text { rial integrity." ( } 12.08 .2019 \text { ) }\end{array}$ \\
\hline
\end{tabular}

Source: own elaboration. 


\section{Chart 2. Topics published in CCTV}

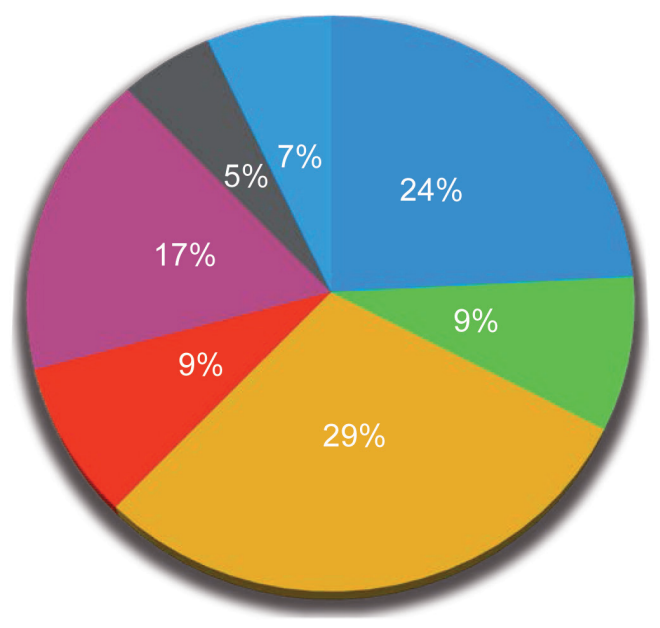

Reports on the course of protests $-24 \%$

Brutality of the protesters and attacks on the police and other people $-9 \%$

Interference in China's internal affairs - 29\%

External support for China's activities in Hong Kong - 9\%

Support of residents and other entities for the actions of authorities and police $-17 \%$

Effects of protests $-5 \%$

Other - 7\%

A total of 58 texts were published on the CCTV website during the period considered. The content was selected in the materials, building a contextual model involving a message solely related to the subject presenting the PRC's position on the events in Hong Kong. The contextual model emphasized the fact that the protests were the result of interference by third countries (mainly the USA but Canada and Great Britain were also indicated) in China's internal affairs. One of the texts referred to the control of events in Hong Kong in the same way as it was previously done in Moscow - through the interference of Western media. The protesters' actions were called "neo-extremism" or "terrorism". Storytelling-building content about events in Hong Kong was burdened with a high level of emotionality and addressed mainly to internal public opinion (Chinese society on the mainland, supporters of integration with mainland China in Hong Kong and Chinese minorities in other countries), to which persuasive and emotional messages were addressed channeling the way of thinking about the events in Hong Kong. The contextual model built by CCTV indicated that the protests in Hong Kong were controlled by specific entities within the region and other countries (mainly the USA), which constitutes interference in the internal affairs of the PRC. Protesters are violent, police actions are reactive, resulting from the need for self-defense and the intention 
to restore public order. The activities of the Hong Kong administration and the police are supported by both individuals and organizations in Hong Kong itself and the Chinese diaspora in other countries, as well as politicians emphasizing that Hong Kong is Chinese. The content published on the CCTV website also highlighted the consequences of the protests that hit Hong Kong residents and resulted from the collapse of tourism and related industries.

\section{Table 2. Examples of content published on the CCTV website}

\begin{tabular}{|c|c|}
\hline Categorization key & $\begin{array}{l}\text { Excerpts from articles published on the subject } \\
\text { indicated along with the date of publication }\end{array}$ \\
\hline Reports on the course of protests & $\begin{array}{l}\text { "Three leaders of political groups advocating } \\
\text { 'Hong Kong's independence, Joshua Wong Chi- } \\
\text {-fung, Agnes Chow Ting and Andy Chan Ho-tin, } \\
\text { have been detained, Hong Kong police confirmed } \\
\text { Friday. } \\
\text { Wong was arrested at around 7:30 a.m. Friday en- } \\
\text { route to the South Horizons MTR station, accord- } \\
\text { ing to the social network account of his group } \\
\text { Demosisto." ( } 30.08 .2019 \text { ) } \\
\text { "The Hong Kong Special Administrative Region } \\
\text { (HKSAR) government will start work immedi- } \\
\text { ately on building a platform for dialogue among } \\
\text { all walks of life, the HKSAR Chief Executive } \\
\text { Carrie Lam said Tuesday. While meeting the } \\
\text { press, Lam said she hopes all sides can show } \\
\text { understanding and respect toward each other, and } \\
\text { conduct dialogues in an open and direct manner } \\
\text { with people of all classes with different political } \\
\text { stances and backgrounds in a bid to find a way out } \\
\text { for Hong Kong." (20.08.2019) } \\
\text { "Starting from June, Hong Kong's opposition } \\
\text { and some radical forces have used the pretext } \\
\text { of peaceful demonstration to engage in violent } \\
\text { protests. (...) Here is a timeline of these } \\
\text { violent activities that are aimed to trample the rule } \\
\text { of law, sabotage social order, undermine national } \\
\text { sovereignty and the 'one country, two systems' } \\
\text { principle." (18.08.2019) }\end{array}$ \\
\hline Interference in China's internal affairs & $\begin{array}{l}\text { "Multiple videos of a boy leading protestors in } \\
\text { shouting slogans on the streets of Hong Kong have } \\
\text { become a cliche of protest publicity. Having a fren- } \\
\text { zied crowd follow a child's innocent voice may be } \\
\text { quite a spectacle. But the question is: Did the boy } \\
\text { really understand what he was doing? The nefari- } \\
\text { ous forces behind the prolonged protests in Hong } \\
\text { Kong have been inciting teenagers, students and } \\
\text { even children to charge onto the streets for their } \\
\text { agenda. Among the suspects arrested for violent } \\
\text { activities since June, many were young faces. One } \\
\text { was only } 12 \text { years old." (30.08.2019) }\end{array}$ \\
\hline
\end{tabular}


Interference in China's internal affairs

"China on Tuesday voiced strong dissatisfaction with and resolute opposition to 'random accusations' and 'irresponsible remarks' on Hong Kong affairs in a statement from the Group of Seven (G7) summit. (...) As we have emphasized on many occasions, Hong Kong affairs are purely China's internal affairs, and no foreign governments, organizations or individuals have the right to intervene', said Geng, when responding to a query about China's comment on the statement from the G7 summit." (28.08.2019)

"The activities of some external powers in Russia are exactly the same as what they have done in Hong Kong, a Chinese Foreign Ministry spokesperson said Tuesday. (...) According to media, the U.S. Embassy in Russia has accused Russia of restricting citizens' exercises of basic rights. The embassy website also published the route map of the rally scheduled in downtown Moscow." (21.08.2019)

"Hong Kong is part of China and foreign forces must stop interfering in Hong Kong's affairs, Chinese ambassador to Britain Liu Xiaoming said here Thursday. Evidence shows that the situation in Hong Kong would not have deteriorated so much had it not been for the interference and incitement of foreign forces, Liu told a press conference at the Chinese Embassy in Britain.” (16.08.2019)

Brutality of the protesters and attacks on the police and other people
"On a rainy August evening, police officers carrying shields faced off with violent protesters who recklessly threw bricks and petrol bombs at them. As officers were ready to disperse them, many charged on and assailed them with metal rods. (...) Over the weekend, 21 police officers were injured, and one suffered heavy stab wounds to his back. The new casualties brought the number of officer injuries to over 200 since June 9." (28.08.2019)

"Protests turned violent in Tsuen Wan, in the western New Territories of Hong Kong, on Sunday as radical protesters hurled petrol bombs at police officers and brutally assaulted them. Several police officers were injured after they were attacked by rioters while they were on duty in Tsuen Wan." (26.08.2019)

"Violent protesters staged a shameful episode of sheer violence and brutality in full public view and broadcast on live television at the Hong Kong International Airport on Tuesday. At about 8 p.m., a group of protesters detained a traveler they claimed to be an undercover police officer from the Chinese mainland. In lynch mob-style assaults, they repeatedly kicked and punched the man, tied his wrists together and pulled his identity documents from his wallet." (16.08.2019) 


\begin{tabular}{|c|c|}
\hline $\begin{array}{l}\text { External support for China's activities in Hong } \\
\text { Kong }\end{array}$ & $\begin{array}{l}\text { "Hundreds of Chinese held a peaceful rally Sun- } \\
\text { day morning to support Hong Kong as an indispu- } \\
\text { table part of China and oppose violence in the spe- } \\
\text { cial administrative region. Waving placards saying } \\
\text { 'No Riots in Hong Kong' in Monterey Park, an } \\
\text { East Los Angeles suburban city, the participants, } \\
\text { including white-collar workers, business owners } \\
\text { and students, all expressed concern and said the } \\
\text { violence by radical protesters in Hong Kong over } \\
\text { the past weeks should by no means be tolerated." } \\
\text { (27.08.2019) } \\
\text { "On Saturday, hundreds of Chinese students and } \\
\text { overseas Chinese in the United Kingdom gathered } \\
\text { at London's Trafalgar Square to protest the 'inde- } \\
\text { pendence demonstration' in Hong Kong. Demon- } \\
\text { strators at London's landmark square waved Chi- } \\
\text { nese flags, sang the Chinese national anthem and } \\
\text { chanted 'no violence' and 'one nation, one China'. } \\
\text { One said he came to express his support for Hong } \\
\text { Kong and its police, and his objection to separa- } \\
\text { tists." (19.08.2019) }\end{array}$ \\
\hline $\begin{array}{l}\text { External support for China's activities in Hong } \\
\text { Kong }\end{array}$ & $\begin{array}{l}\text { "Foreign government officials and experts slam- } \\
\text { med the violence perpetrated by radical protesters } \\
\text { in China's Hong Kong Special Administrative Re- } \\
\text { gion and voiced support for the legitimate actions } \\
\text { taken by the HKSAR government and local police } \\
\text { to restore order. Mohammad Faisal, a spokesman } \\
\text { for Pakistan's Ministry of Foreign Affairs, said } \\
\text { Hong Kong affairs are completely China's internal } \\
\text { affairs, and Pakistan understands the actions taken } \\
\text { by the Chinese central government and the HKSAR } \\
\text { government to uphold national sovereignty and } \\
\text { maintain the city's prosperity and stability. Helen } \\
\text { Sham-Ho, a former Australian politician, said the } \\
\text { current chaotic situation in Hong Kong is damag- } \\
\text { ing its prosperity, adding that there is no doubt } \\
\text { that the priority is to regain order and police have } \\
\text { the right to uphold law and order. Michael Borch- } \\
\text { mann, a law expert and former government offi- } \\
\text { cial from Germany, said that the purpose of the } \\
\text { ongoing protests in Hong Kong is to stir up chaos } \\
\text { and turmoil in the city, and is not a response to } \\
\text { the draft extradition bill, Nouvelles d'Europe cited } \\
\text { him as saying." (15.08.2019) }\end{array}$ \\
\hline
\end{tabular}


Support of residents and other entities for the actions of authorities and police
"More than 100 people held a demonstration on Monday in front of the U.S. Consulate General in China's Hong Kong Special Administrative Region (HKSAR) to protest against the U.S. interference in China's domestic affairs." (27.08.2019)

"Nearly 600 taxis on Friday participated here in a peace rally against violence and showed Hong Kong residents' love for their home and the motherland. The rally, organized by civil group Safeguard Hong Kong and Hong Kong Taxi Drivers and Operators Association, was aimed at urging the Hong Kong community to jointly oppose violence and restore social order as soon as possible, said the organizers." (24.08.2019)

"Large groups of Hong Kong people visited several police stations in Hong Kong Saturday to express their firm support for and utmost respect to the police force. The scene stood in stark contrast to the chaotic and violent besieges of police stations by black-clad protesters on many nights over the past weeks." (11.08.2019)

Effects of protests
"The flagrant violence has already taken a heavy toll on Hong Kong's already-weak economy. Tourism sector has turned from a summer boom into a chilly winter. The HKSAR government has announced a package of economy-boosting measures." (19.08.2019)

"The Hong Kong police said on Wednesday that they had arrested five people involved in unlawful assembly at the Hong Kong International Airport. Radical protesters held an unlawful assembly at the airport on Tuesday evening. Two residents from the mainland were assaulted and unlawfully detained. The five males arrested are aged between 17 and 28, with two of them suspected of assaulting police and possessing offensive weapons." (15.08.2019)

"Leung Chun-ying, vice chairman of the National Committee of the Chinese People's Political Consultative Conference, on Wednesday urged Hong Kong residents to provide clues to help bring radicals who blocked the airport and attacked a traveler and a reporter to justice." (11.08.2019) 


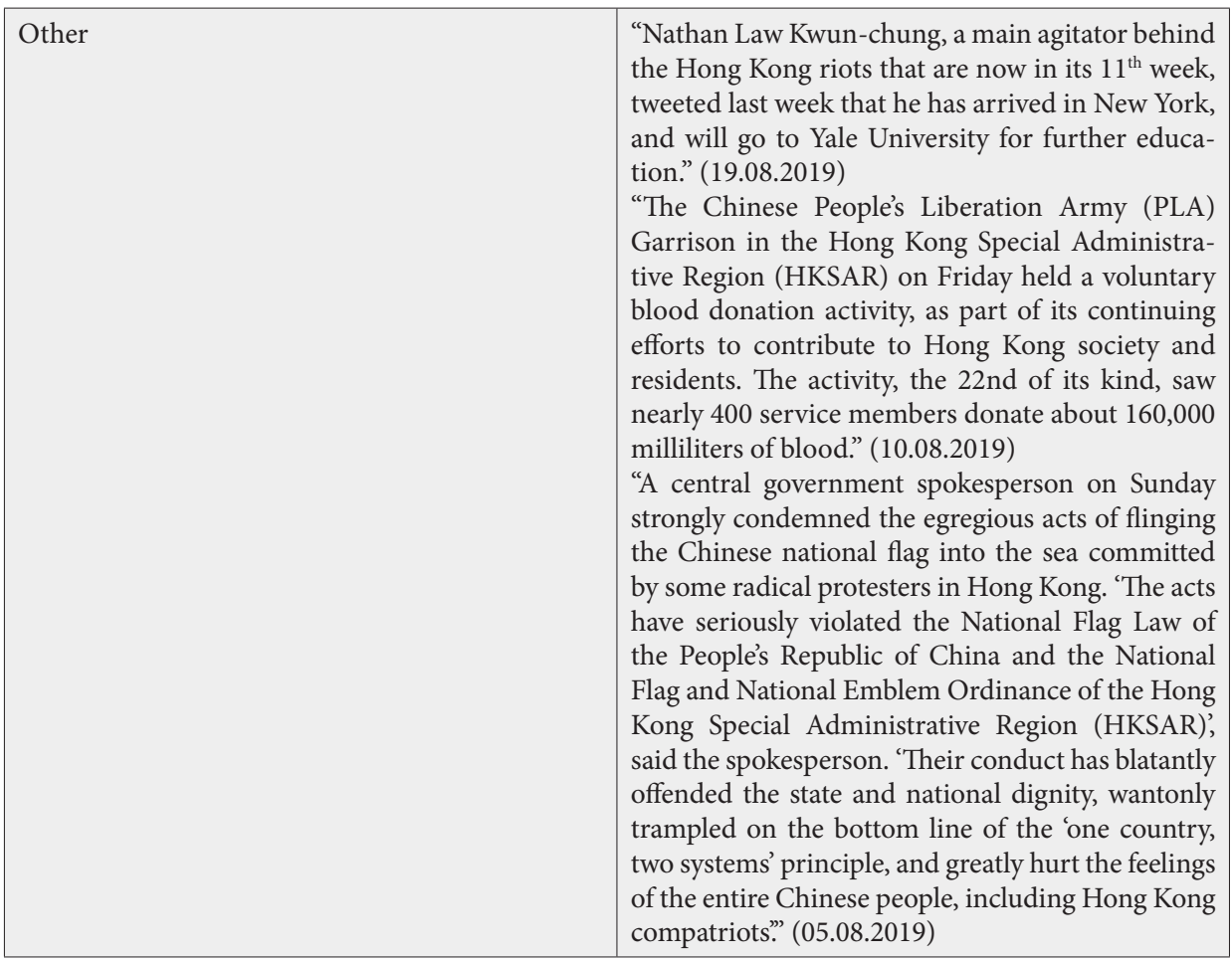

Source: own elaboration.

In the texts published on televisions' websites, protesters in Hong Kong were attributed certain names (see Table 3), which created negative emotional messages. Both television (RT and CCTV) used classic propaganda technique of demonisation of protesters in Hong Kong. Terms used to describe protesters create them as a people who want to destroy existing public order through rebellion and acts of terrorism.

Table 3. Terms used for protesters in Hong Kong

\begin{tabular}{|l|l|}
\hline RT & CCTV \\
\hline "criminal elements" & "separatists" \\
\hline "violent extremists" & "radical protesters" / "brutal protesters" \\
\hline "terrorist activists" & "violent demonstrators" \\
\hline "radical demonstrators" & "mobsters" \\
\hline
\end{tabular}

Source: own elaboration. 
To sum up the findings, several conclusions can be indicated for discussion:

1. Each television has built a one-sided message aimed at its audience. None of the materials published on both TV channels have developed reasons for the protest and have not been embedded in the political and social context, only information about the protests has been provided. The narrative specified and directed emotionally-marked storytelling while referring to the negative names describing the demonstrators, which further strengthened the message.

2. A similar contextual model was built in both televisions, although due to different target groups, it differed in those elements that were important from the point of view of ideology being taken into account when selecting information by each of the broadcasters. The RT narrative model was primarily concerned with US protest control and its interference in Mainland China's internal affairs, while the CCTV's narrative raised these issues, but it was also based on identifying policy supporters (both among citizens and organizations and politicians) and justified police activities. The differences in the built contextual model should be justified by taking into account the variable, which is the location of protests to the sender of propaganda messages. For RT, protests were a circumstance that allowed the use of storytelling, in which the sender could formulate communication acts using the ideology of propaganda. For CCTV, acts of civic resistance are an internal political and social problem in which storytelling was used to reveal the polarized society of Hong Kong and to activate Chinese nationalism.

3. The terms used to describe protesters had emotional overtones, indicating negative assessments of their actions in both cases. However, in the contextual models of both TV stations, the negative assessment of the protesters had a different dimension. In the CCTV's contextual model, the protesters were the group which the messages fought against (it was revealed that the actions of the protesters were not supported by the residents and organized groups, Hong Kong residents and businesses lose out because of the protests, etc.). RT built a contextual model in which the protesters were a rather unconscious and manipulated crowd, just like in other countries (including Russia, Ukraine or Syria), where Russian internal or foreign policy is contested as a result of protests. For RT, protests in Hong Kong were rather a pretext to disseminate the theory in which the protests have nothing to do with grassroot civic activities, but are the result of external crowd control, using Western mass media and social media.

4. In both televisions in the categorization key, in which there were a total of 7 differently named items, a common category "other" appeared. $21 \%$ of the materials fell into this category in RT, 7\% of content in CCTV. This indicates that the contextual model built by CCTV was more specific, due to the propaganda goals to be achieved - promoting the principles of "public order", 
"peaceful development", "social stability" and respecting hierarchy and the supreme role of the authorities. In the case of RT, the model was based on achieving propaganda goals using conspiracy theories. Due to the relations to the protest, it required an extensive narrative context (non-transparent activities of social networking sites removing Chinese accounts, unclear actions of mass media reporting on selected protests and ignoring others, interference and control of protests by external entities with their own goals to achieve - trade war between the US and China), of which Russian propaganda interests were part of.

\section{Conclusion}

Completed research confirmed the adopted hypothesis that propaganda activities are carried out as a result of the selection of information forming a contextual model in which the story is unilaterally and emotionally told in accordance with the propaganda ideology adopted by the broadcaster. The variable used in the research indicated that the narrative in the contextual model allows the use of events that seemingly have nothing to do with the policy pursued by the holder of the propaganda media (Russia) to build a story consistent with the view of the world that the broadcaster wants to promote. This means that actions that remain in the sphere of political or social influence of third countries can also become a source of creation of a contextual model that allows achieving propaganda goals also by external broadcasters. Ideology, understood as a way of seeing and interpreting the world, is therefore an important source of danger in the case of television serving propaganda functions, due to the way they build messages - using seemingly objective journalism and building reach thanks to the existence of social media, enabling the activity of a polarized community built around a specific communication channel.

\section{Bibliography}

Bird E., Dardenne R.W. (2009). "Rethinking News and Myth as Storytelling News, Discourse, and Ideology”. In: K. Wahl-Jorgensen, T. Hanitzsch (eds.), The Handbook of Journalism Studies (pp. 205-217). New York: Routledge.

Bird S.E., Dardenne R.W. (1988). "Myth, Chronicle, and Story: Exploring the Narrative Qualities of News". In: J.W. Carey (ed.), Media, Myths, and Narratives (pp. 67-87). Beverly Hills, CA: Sage Publications.

Bossio D. (2017). Journalism and Social Media: Practitioners, Organisations and Institutions. London: Palgrave Macmillan.

Cull N.J. (2019). Public Diplomacy: Foundations for Global Engagement in the Digital Age (Contemporary Political Communication). Cambridge: Polity Press. 
Darczewska J. (2014). Anatomia rosyjskiej wojny informacyjnej. Operacja krymska - studium przypadku. Warszawa: Centre for Eastern Studies.

Dotson J. (2011). The Confucian Revival in the Propaganda Narratives of the Chinese Government. Retrieved from: https://www.uscc.gov/sites/default/files/Research/Confucian_ Revival_Paper.pdf.

Edney K. (2014). The Globalization of Chinese Propaganda: International Power and Domestic Political Cohesion. New York: Palgrave Macmillan.

Fenster M. (1999). Conspiracy Theories: Secrecy and Power in American Culture. $1^{\text {st }}$ ed. Minneapolis: University of Minnesota Press.

Fenster M. (2008). Conspiracy Theories: Secrecy and Power in American Culture. $2^{\text {nd }}$ ed. Minneapolis: University of Minnesota Press.

Herman E.S., Chomsky N. (1988). Manufacturing Consent: The Political Economy of the Mass Media. New York: Pantheon Books.

Jenkins H. (2008). Convergence Culture: Where Old and New Media Collide. New York: New York University Press.

Jowett G.S., O’Donnel V. (1999). Propaganda and Persuasion. Thousand Oaks-London: Sage Publications.

Keen A. (2007). The Cult of the Amateur: How Today's Internet Is Killing Our Culture. New York: Doubleday.

Kershaw I. (1983). “How Effective Was Nazi Propaganda?”. In: D. Welch (ed.), The Power and the Limitations (pp. 180-205). London: Routledge.

Laclau E. (2005). “Populism: What's in a Name?”. In: F. Panizza (ed.), Populism and the Mirror of Democracy (pp. 32-49). London: Verso.

Lasswell H.D. (2013). Propaganda Technique in the World War. Eastford: Martino Fine Books. Lo S.S.-H., Hung, S.Ch.-F., Loo J.H.-Ch. (2019). "A Comprehensive Framework of Understanding the Context and Content of China's New United Front Work on Hong Kong”. In: S.S.-H. Lo, S.Ch.-F. Hung, J.H.-Ch. Loo (eds.), China's New United Front Work in Hong Kong: Penetrative Politics and Its Implications (pp. 1-42). New York: Palgrave Macmillan.

Lui T.L. (2015). "A Missing Page in the Grand Plan of "One Country, Two Systems": Regional Integration and its Challenges to Post-1997 Hong Kong". Inter-Asia Cultural Studies, Vol. 16(3), pp. 396-409.

Ma N. (2015). “The Rise of "Anti-China" Sentiments in Hong Kong and the 2012 Legislative Council Elections". China Review, Vol. 15(1), pp. 39-66.

Maffesoli M. (1996). The Time of the Tribes: The Decline of Individualism in Mass Society. London: Sage Publications.

McQuail D. (2000) Media Performance: Mass Communication and the Public Interest. London: Sage Publications.

McQuail D. (2010). Mass Communication Theory. $6^{\text {th }}$ ed. London: Sage Publications.

Mihailidis P., Viotty S. (2017). "Spreadable Spectacle in Digital Culture: Civic Expression, Fake News and the Role of Media Literacies in "Post-Fact" Society". American Behavioural Science, Vol. 61(4), pp. 441-454.

O'Shaughnessy N. (2012). "The Death and Life of Propaganda”. Journal of Public Affairs, Vol. 12(1), pp. 29-38.

Pamment J. (2013). New Public Diplomacy in the 21 $1^{\text {st }}$ Century: A Comparative Study of Policy and Practice. London: Routledge.

Rawnsley G. (2015). “To Know Us Is to Love Us: Public Diplomacy and International Broadcasting in Contemporary Russia and China”. Politics, Vol. 35(3-4), pp. 273-286. 
Rieger D.R., Frischling L., Bente G. (2013). Propaganda 2.0: Psychological Effects of Right-wing and Islamic Extremist Internet Videos. Cologne: Wolters Kluwer.

Saari S. (2014). "Russia's Post-Orange Revolution Strategies to Increase Its Influence in Former Soviet Republics: Public Diplomacy po russkii”. Europe-Asia Studies, Vol. 66(1), pp. 50-66.

Sunstein C.S. (2018). \#Republic: Divided Democracy in the Age of Social Media. PrincetonOxford: Princeton University Press.

Taylor P. (2003). Munitions of the Mind: A History of Propaganda from the Ancient World to the Present Era. Manchester-New York: Manchester University Press.

Yablokov I. (2015). "Conspiracy Theories as a Russian Public Diplomacy Tool: The Case of Russia Today (RT)”. Politics, Vol. 35(3-4), pp. 301-315.

Van Dijk T.A. (2009). "News, Discourse, and Ideology". In: K. Wahl-Jorgensen, T. Hanitzsch (eds.), The Handbook of Journalism Studies (pp. 191-204). New York: Routledge.

Watts C. (2018). Messing with the Enemy: Surviving in a Social Media World of Hackers, Terrorists, Russians and Fake News. New York: Harper.

Zhang H. (2011). "The Globalization of Chinese Television: The Role of the Party-State”. The International Communication Gazette, Vol. 73(7), pp. 573-594. 